\title{
СВЯЗЬ ЦЕННОСТНО-СМЫСЛОВОЙ СФЕРЫ И ПРЕДСТАВЛЕНИЙ О СЕМЕЙНОЙ ЖИЗНИ У МОЛОДЕЖИ
}

\section{THE CONNECTION OF THE VALUE- SEMANTIC SPHERE AND IDEAS ABOUT FAMILY LIFE AMONG YOUNG PEOPLE \\ Yu. Buzykina \\ S. Tarasov}

Summary: The article presents the results of a study of the value-semantic sphere and ideas about family life among young people. The dominant semantic basic attitudes, meaning-life and value orientations of young people, as well as ideas about the family are revealed. The description of associations with the word "family» is given. The connections of terminal and instrumental values, as well as semantic basic attitudes with indicators of life-meaning orientations are established. The description of ideas about family life depending on the prevailing value orientations of young people is given.

Keywords: terminal and instrumental values, life-meaning orientations, semantic basic attitudes, associations, ideas about the family, youth.
Бузыкина Юлия Сергеевна

к.nсх.н., доцент, ФГБОУ ВО «Пензенский государственный университет»

ylamart@yandex.ru

Тарасов Сергей Васильевич

к.nсх.н., доцент, ФГБОУ ВО «Пензенский государственный

университет»

omko08@mail.ru

Аннотация: В статье представлены результаты исследования ценностносмысловой сферы и представлений о семейной жизни у молодежи. Выявлены доминирующие смысловые базовые установки, смысложизненные и ценностные ориентации молодежи, а также представления о семье. Дано описание ассоциаций со словом «семья». Установлены связи терминальных и инструментальных ценностей, а также смысловых базовых установок с показателями смысложизненных ориентаций. Дано описание представлений 0 семейной жизни в зависимости от преобладающих ценностных ориентаций молодежи.

Ключевые слова: терминальные и инструментальные ценности, смысложизненные ориентации, смысловые базовые установки, ассоциации, представления о семье, молодежь.

стве. Таким образом, изучение представлений о семье выступает актуальной проблемой, требующей серьезного осмысления.

В настоящее время можно наблюдать негативные тенденции в брачно-семейных отношениях в молодежной среде, где увеличивается число разводов, снижается нравственно-психологический климат, ухудшаются нравственные нормы, ориентиры смещаются на профессионально-карьерные ценности, чем семейные.

Современные отечественные исследования, направленные на изучение жизненных ценностей, ярко свидетельствуют об индивидуализации молодежи. Можно выделить две складывающиеся тенденции в отношении семейных ценностей: полярность ценностных отношений среди членов семьи (зачастую детей и родителей); появление, отличающихся от традиционно сложившихся, целей, интересов, идеалов и убеждений членов семьи, а также деформация семейных ценностей в целом $[3,4 ; 6$, c. 156].

Проблему исследования составило противоречие между достаточно тщательной изученностью ценностно-смысловой сферы личности, и недостатком комплексных психологических исследований о роли ценностносмысловой сферы в формировании представлений о семейной жизни в молодежной среде. 
Теоретической основой исследования выступили работы Д.А. Леонтьева [9], А. Маслоу, В. Франкла по изучению роли смысловой сферы и личностных ценностей в организации жизни и деятельности человека, подходы к исследованию семьи (Г.М. Андреева [2], А.Я. Варга [5], И.М. Желдак [7], О.Л. Зверева, О.А. Карабанова [8], А.А. Реан [10] и др.) и представлений о семье в молодежной среде (М.И. Андросова [3], Е.Л. Бокуть [4], Е.В. Дворникова, А.В. Кошелева [6] и др.)

Эмпирическое исследование было проведено на базе ФГБОУ ВО «Пензенский государственный университет». Выборку составили 50 студентов в возрасте 19-24 лет.

В ходе исследования были использованы следующие методики: «Смысловые базовые установки» (СБУ) А.Д. Ишкова, Н.Г. Милорадовой; «Ценностные ориентации» М. Рокича; тест смысложизненных ориентаций (СЖО) Д.А. Леонтьева; метод свободных ассоциаций со словом «семья»; анкета «Представление о семейной жизни».

Полученные результаты были подвергнуты математико-статистической обработке данных с помощью критерия ранговой корреляции Спирмена.

Установлено, что доминирующими терминальными ценностями для испытуемых являются: счастливая семейная жизнь, любовь, здоровье, уверенность в себе, развитие, активная деятельная жизнь.

Наиболее значимыми среди инструментальных ценностей по выборке выступают: честность, воспитанность, жизнерадостность, ответственность, самоконтроль и образованность.

В результате анализа смысложизненных ориентаций было выявлено, что у большинства испытуемых есть жизненные цели, при достижении которых у них появляется уверенность в способности ставить перед собой цели и добиваться результатов. Благодаря наличию жизненных целей их жизнь наделяется смыслом. Они адекватно воспринимают процесс своей жизни, который в меру наполнен эмоциональной составляющей. Молодые люди способны давать адекватную оценку пройденному этапу в жизни. У них доминирует представление о себе, как о сильной личности, обладающей достаточной свободой выбора. Они стремятся к воплощению в жизнь своих принятых решений.

В результате анализа данных, полученных по опроснику «Смысловые базовые установки» (СБУ) А.Д. Ишкова, Н.Г. Милорадовой, можно сказать, что:

- по шкале «вербальная зависимость» у 44\% испы- туемых преобладает высокий уровень выраженности. Они чрезмерно зависят от мнения окружающих, чутко реагируют на высказывания в свой адрес;

- по шкале «эмоциональная зависимость» у 44\% преобладает низкий уровень выраженности, что может говорить об их эмоциональной неустойчивости («холодности») или стремлении скрывать свои переживания;

- по шкале «требовательность к себе» у 38\% испытуемых преобладает средний уровень. Как правило, это аккуратные, организованные люди с адекватной требовательностью к себе;

- по шкале «ответственность за себя» преобладает высокий уровень (у 48\% испытуемых). Они способны реалистично оценивать ситуацию и считают, что все происходящее с ними зависит исключительно от них.

Метод свободных ассоциаций со словом «семья» позволил выделить четыре ключевые категории, такие как: общение, отношения; личностные переживания, эмоции; материальная, хозяйственно-бытовая сфера; семейные роли.

Проанализировав ответы испытуемых по анкете «Представление о семейной жизни», можно сказать, что:

- для 72\% испытуемых создание семьи является одной из важнейших целей в их жизни;

- для 56\% опрошенных семейная жизнь их родителей является образцом для создания своей будущей семьи;

- для 52\% испытуемых материальное положение партнера не является наиболее важным фактором;

- рождение детей в семейной жизни для $72 \%$ испытуемых наиболее важная ценность;

- главной отрицательной стороной в семейной жизни в 68\% случаев молодые люди отметили «навешивание ярлыков»;

- 58\% испытуемых считают, что основная функция семьи заключается в эмоциональном и духовном общении;

- для 62\% испытуемых взаимопонимание является наиболее важным в семейной жизни, любовь для 42\%;

- по мнению испытуемых, средний возраст для вступления в брак для женщин - от 23 до 28 лет, для мужчин - от 23 до 30 лет.

По результатам математико-статистической обработки данных были выявлены следующие связи:

- терминальной ценности «свобода» и целей в жизни $\left(r_{s}=0,386\right.$ при $\left.p \leq 0,01\right)$. Так, молодые люди по выборке предпочитают, чтобы супруги занима- 
ли одинаковую позицию в семье и считают, что семейные обязанности должны распределяться одинаково. Данные результаты согласуются с результатами исследований. Так, Бокуть Е.Л. отмечает, что большинство опрошенных студентов выделяют эгалитарную модель семьи, как предпочтительную [4, с. 34]. Отрицательные стороны в семейной жизни, по их мнению, - ограничение каких-либо личных желаний и навешивание ярлыков. Семья ассоциируется у них с любовью, уважением, заботой, счастьем, поддержкой, близкими людьми, теплом, домом и опорой. Свобода их личности, не смотря на наличие семьи, является важной целью, к которой они будут стремиться. Ограничение желаний, возможностей, постоянная ответственность могут оказывать на них отрицательное влияние;

- связь инструментальной ценности «воспитанность» и целей в жизни ( $r_{s}=0,361$ при $\left.p \leq 0,01\right)$. Так, основные функции, которые выполняет семья, по мнению молодежи, это репродуктивная, воспитательная, а также функции эмоционального и духовного общения. Главным в семье должен быть мужчина. Наиболее значимыми аспектами в семье являются взаимная поддержка, чувство защищенности, взаимоуважение, любовь, честность, равноправие и т.д. Данными испытуемыми дано следующее описание своих семей: традиционная, среднестатистическая, счастливая, любящая, понимающая, а также гиперопекаемая, замкнутая, строгая, ограничивающая. На основании этого можно предположить, что в жизни данных испытуемых процесс воспитания занимает одно из ведущих мест и личностное развитие может выступать в качестве ведущей жизненной цели;

- связь инструментальной ценности «исполнительность» и результативности жизни $\left(r_{s}=0,271\right.$ при $\mathrm{p} \leq 0,05)$. Это говорит о том, что для испытуемых наиболее важными факторами для существования семьи являются ответственность, общие интересы, верность, любовь, умение слышать и слушать друг друга. Исполнительность может являться одним из главных показателей стабильности семейных отношений, что так или иначе, будет влиять на оценку ими пройденного этапа семейной жизни. Семья ассоциируется у них с близкими людьми, заботой, любовью, пониманием, детьми, преданностью, искренностью, спокойствием;

- обратная связь шкалы «требовательность к себе» и процесса жизни ( $r_{s}=-0,306$ при $\left.p \leq 0,05\right)$. Данные испытуемые отличаются достаточно высокой требовательностью к себе в семейной жизни. Они способны объективно оценивать себя в отношениях. В семейной жизни могут стремиться к под- держанию определенной планки, состоящей из набора социальных требований к партнеру, которые, по их мнению, являются ключевыми для поддержания счастливой семейной жизни. Однако, соблюдение постоянных требований предполагает большую самоотдачу, в результате они не получают внутренней удовлетворенности, хотя их семейные взаимоотношения могут быть вполне счастливыми;

- связь инструментальной ценности «рационализм» и шкалы ответственности за других $\left(r_{s}=0,445\right.$ при $\left.p \leq 0,01\right)$. Молодые люди с доминированием ценности «рационализм» считают, что семья выполняет функцию эмоционального и духовного общения. Для создания семьи важно наличие у партнеров взаимных чувств. Также в их представлении супруги должны занимать одинаковую позицию, а семейные обязанности распределяться поровну. Умение решать конфликты и наличие общих взглядов на жизнь являются важнейшими факторами для сохранения семьи, которая ассоциируется с поддержкой, уютом, уважением, заботой и близостью. Данные испытуемые не поддаются эмоциям в принятии какихлибо решений, а опираются на конкретные факты. В семейной жизни чувствуют ответственность за своего партнера;

- связь инструментальной ценности «широта взглядов» и требовательности к себе $\left(r_{s}=0,469\right.$ при $\mathrm{p} \leq 0,01)$. Так, испытуемые с доминированием ценности «широта взглядов» считают, что создание семьи является важнейшей целью. По их мнению, семья выполняет функцию эмоционального и духовного общения, а также закладывает основные ценности, такие как: чуткость, ответственность за свои поступки, сохранение традиций, взаимоуважение. Молодые люди считают, что оба супруга должны занимать одинаковую позицию в семье. Ограничение личных желаний, отсутствие гибкости, консервативность выступают отрицательными сторонами семейной жизни. Наиболее важными в семейной жизни для них являются: поддержка, взаимные чувства, духовная близость, бережное отношение к личному пространству друг друга. Испытуемые в семейных отношениях способны понять точку зрения своего партнера, относятся с уважением к его привычкам, вкусам, выборам в определенных вариантах. Все это говорит о широте их взглядов и возможности объективной оценки себя и окружающих.

Данные, полученные в ходе исследования, могут быть использованы в работе с молодежью по их подготовке к семейной жизни. 


\section{ЛИТЕРАТУРА}

1. Абрамова Г.С. Возрастная психология: учеб. пособие для студ. вузов. - М.: Изд. центр «Академия»: Раритет, 1997. - 704 с.

2. Андреева Г.М. Социальная психология. - М.: Аспект Пресс, 2017. - 363 с.

3. Андросова М.И., Афанасьева Л.И. Образ семьи в представлении студентов [Электронный ресурс]. - URL: https://cyberleninka.ru/article/n/obraz-semi-vpredstavlenii-studentov/viewer (дата обращения: 22.09.2021).

4. Бокуть Е.Л. Представления о семье студентов педагогического университета // Вестник Челябинского государственного педагогического университета. 2018. - №2. - C. 30-38.

5. Варга А.Я. Обучение студенческой молодёжи семейной психотерапии: проблемы и вызовы // Высшая школа: опыт, проблемы, перспективы материалы VIII Международной научно-практической конференции: в 2 ч. Российский университет дружбы народов; науч. ред. В.И. Казаренков. - М., 2015. C. 182-186.

6. Дворникова Е.В., Кошелева А.В. Программный подход по формированию представлений о семейных отношениях у современной студенческой молодежи // Вестник Костромского государственного университета. - 2019. - Т.25. - №3 - С. 156-160.

7. Желдак И.М. Искусство быть семьёй / И.М. Желдак. - М.: МП Леокс, 2012. - 230 с.

8. Карабанова 0.А. Детско-родительские отношения и практика воспитания в семье: кросскультурный аспект // Современная зарубежная психология. 2017. - T.6. - № 2. - C. 15-26.

9. Леонтьев Д.А. Психология смысла: природа, строение и динамика смысловой реальности. - 3-е изд., доп. - М.: Смысл, 2007. - 510 с.

10. Реан А.А. Семья в структуре ценностей молодёжи // Российский психологический журнал. - 2017. - Т. 14. - № 1. - С. 62-76.

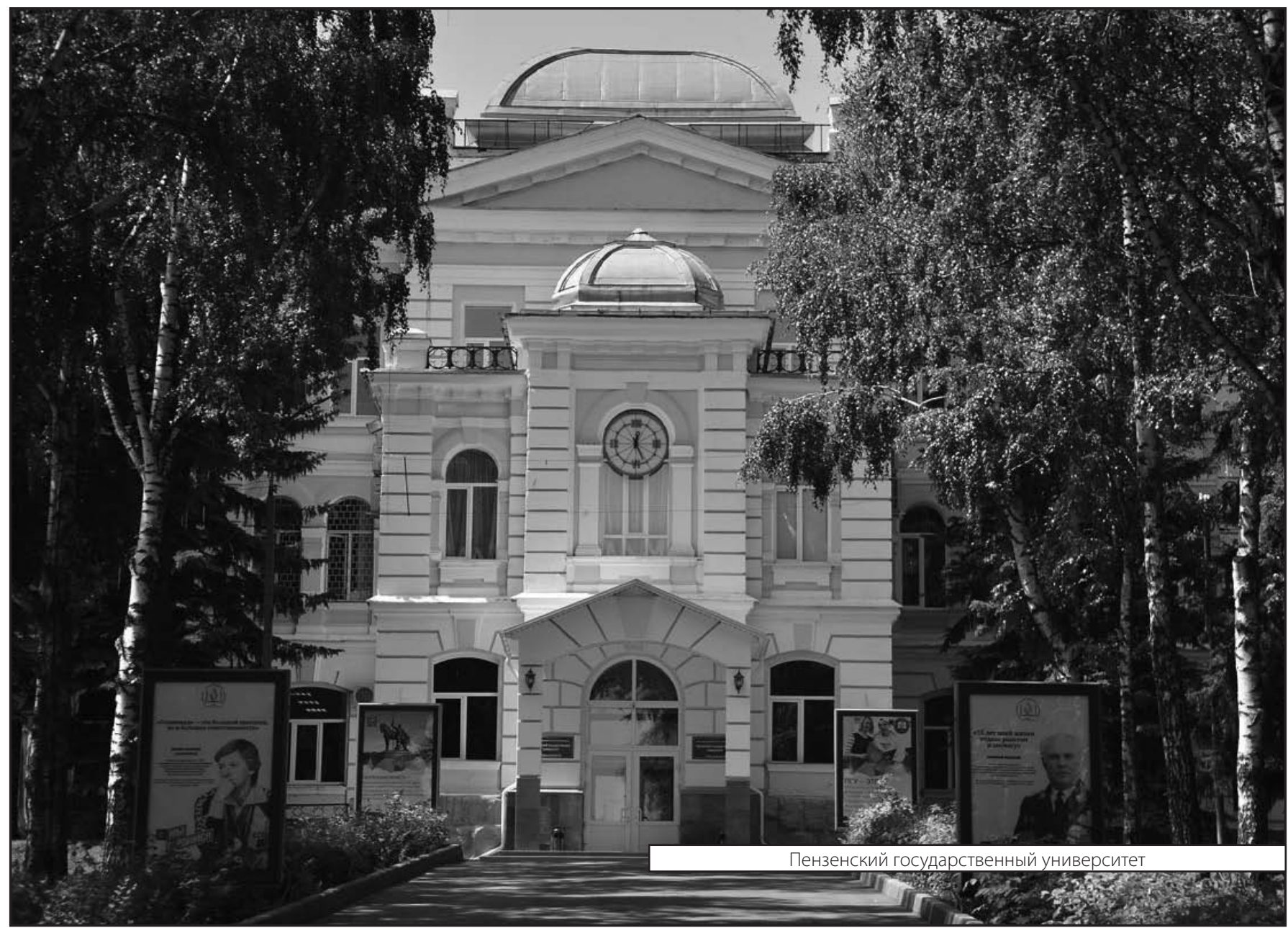

